\title{
Utilizing a Preplant Soil Test for Predicting and Estimating Root Rot Severity in Sugar Beet in the Central High Plains of the United States
}

R. M. Harveson and K. A. Nielsen, Panhandle Research and Extension Center, University of Nebraska, Scottsbluff; and K. M. Eskridge, Department of Statistics, University of Nebraska, Lincoln

\begin{abstract}
Harveson, R. M., Nielsen, K. A., and Eskridge, K. M. 2014. Utilizing a preplant soil test for predicting and estimating root rot severity in sugar beet in the Central High Plains of the United States. Plant Dis. 98:1248-1252.

Aphanomyces cochlioides and Rhizoctonia solani are important soilborne pathogens causing root diseases that are primary constraints to sugar beet production in Nebraska, Colorado, and Wyoming. These types of diseases are difficult to control because they are often not noticed until substantial damage has already occurred. Efforts to manage them would be more effective if techniques were available that were more predictive than reactive. Therefore, a preplant soil test was developed to estimate the relative pathogen populations in the soil and to predict potential root disease problems later in the growing season. Preplant soil samples collected from fields to be sown with sugar beet were planted with a susceptible cultivar and tests were conducted for 1 month in the greenhouse. A preplant disease index was developed based on the time period during the test that seedlings became infected and was calculated on a 0-to-100 scale. Disease index values were

compared with yields obtained from the same fields after harvest. Analysis of data collected for 5 years (2003 to 2007) with analysis of covariance revealed a strong relationship between the preplant disease index values and recoverable sucrose and root yields but not sucrose concentration. Results indicated that, for each unit increase in the preplant disease index, root yield decreased by 0.27 metric tons $(270$ $\mathrm{kg})$ per hectare $\left(P<0.05, R^{2}=0.44\right)$ and recoverable sucrose decreased by $49 \mathrm{~kg} / \mathrm{ha}\left(P<0.05, R^{2}=0.45\right)$. We concluded that this preplant soil test can accurately predict root disease potential due to $R$. solani and $A$. cochlioides, and has the potential to help producers make effective management decisions in production fields using the index procedure. This soil assay has additionally provided new information on the biology, incidence, and distribution of root pathogens in production fields throughout the Central High Plains.
\end{abstract}

In western Nebraska, southeastern Wyoming, and northeastern Colorado, root diseases induced by Rhizoctonia solani (Kühn) and Aphanomyces cochlioides (Drechsler) cause significant problems in sugar beet production. Other root pathogens causing rhizomania and Fusarium yellows and root rot are present in this region but presently cause fewer problems, due to a number of factors. Rhizomania has become much less problematic over the last decade due to the genetic resistance now incorporated into all approved cultivars for the South Region of the Western Sugar Cooperative, while the incidence of the two Fusarium diseases (root rot and wilt) has been erratic from year to year over the same period of time.

$R$. solani, the pathogen that causes Rhizoctonia root and crown rot of sugar beet, has been present in this region for many years $(10,11,16,19,20)$. This disease is well known by industry personnel and is currently considered the most widespread and consistently damaging sugar beet disease in this area $(6,10)$. It appears throughout the growing season and has been documented to result in yield losses as high as $50 \%$ in Nebraska (11). Aphanomyces root rot, caused by $A$. cochlioides, has more recently been identified formally from Nebraska and Wyoming sugar beet fields (5), although it has likely been present throughout this region for some time.

Finding fields infested with both pathogens infecting crops simultaneously is becoming more the norm than the exception. $R$. solani and A. cochlioides possess several common characteristics, including the ability to cause both a seedling disease and a chronic root rot later in the growing season. Additionally, both pathogens are soilborne, can survive in the soil for many years, and are favored by generally warm temperatures and moist soils $(1,6,14$,

Corresponding author: R. M. Harveson, E-mail: rharveson2@unl.edu

Accepted for publication 27 March 2014.

http://dx.doi.org/10.1094/PDIS-11-13-1186-RE

(C) 2014 The American Phytopathological Society
$15,17,18,21)$. Yet they also differ substantially. Taxonomically, they are not closely related, and the zoosporic Aphanomyces is much more dependent upon high levels of soil moisture than Rhizoctonia for disease development and spread (22,23). Additionally, Rhizoctonia spp. infect a wide range of host plants, whereas Aphanomyces spp. are limited to causing disease on plants related to sugar beet $(6,14)$.

Management options are available for both diseases, including seed treatments with several fungicides, resistant cultivars, and cultural practices such as early planting and irrigation management $(1,15)$. Unfortunately, no one management method is adequate when both pathogens are present. Although both pathogens can cause seedling disease, in this region, severe damage is more commonly incurred as acute root rots. Therefore, a predictive technique for the occurrence of Rhizoctonia and Aphanomyces root rots later in the growing season would be useful in estimating disease potential, thus allowing greater flexibility for growers to make management decisions on a timelier basis.

Based on this need, we developed a preplant soil test technique with the purpose of predicting potential root disease problems prior to planting, emphasizing the root rots caused by A. cochlioides and $R$. solani. This test can also identify and estimate populations of other specific soil pathogens utilizing a seedling disease assay performed in the greenhouse. Several preliminary reports on this technique have been previously published $(7,8)$. The objectives of this study were to describe the preplant disease test and evaluate its capabilities for disease prediction based on comparing results with yield parameters from 109 production fields over the 5-year period of 2003 to 2007.

\section{Materials and Methods}

This project was initially started as an expansion of a sugar beet grower service that tested preplant soil samples for the presence of Beet necrotic yellow vein virus, the causal agent of rhizomania. It was conceived after discussions with growers and learning of their desire to proactively obtain similar information on other potential root pathogens residing in their soils in a similar manner as was 
provided for rhizomania. Our resulting test (referred to hereafter as the preplant disease index [PPDI]) was based on a similar concept developed by Ewaldz (3) for estimating the risk of Aphanomyces damping-off of sugar beet seedlings in Sweden.

PPDI procedure. Soil samples were collected by Western Sugar Cooperative agriculturalists or crop consultants and scouts from production fields to be planted to sugar beet the following season. The samples were obtained from the upper 10 to $15 \mathrm{~cm}$ in depth from multiple locations within fields to give a representation of the entire field, similar to those samples taken for preplant fertility analysis. Typically, this included 10 to 12 subsamples per 10 ha, with a final volume of at least 1 liter per field for testing.

The soil from each sample (field) was placed in two $10-\mathrm{cm}-$ diameter plastic pots in the greenhouse (maintained at an ambient air temperatures of 23 to $28^{\circ} \mathrm{C}$. Seed ( 25 per pot) were planted with an nontreated, root-rot-susceptible cultivar ('Monohikari'), with the purpose of baiting the root rot pathogens from the soil samples. Pots were placed within plastic saucers and watered individually from the bottom. After emergence, plants were monitored daily and any infected, symptomatic seedlings were removed and plated on half-strength potato dextrose agar, and the pathogens were identified from characteristic mycelial growth emerging from infected hypocotyls (Fig. 1) $(6,9,21)$. The duration of the test was 4 weeks, and the index was created based on the specific time (week) during the 30-day test when the seedlings became infected. The index was calculated on a 0-to-100 scale based on the formula [DI $=4 \times \mathrm{IS}_{1}+$ $\left.3 \times \mathrm{IS}_{2}+2 \times \mathrm{IS}_{3}+\mathrm{IS}_{4}\right] /[4 \times \mathrm{PE}] \times 100$, where DI is the disease index, IS $\mathrm{S}_{\mathrm{i}}$ is the number of infected seedlings in week $i, \mathrm{PE}$ is the total number of plants emerged, and the subscripts $1,2,3$, and 4 represent the first, second, third, and fourth weeks, respectively, of the test. Index values of 30 to 45 were considered to represent a moderate risk of disease occurrence from the pathogens later in the season. Values above 45 would represent a high risk, while values below 30 were considered to pose a low risk.

Statistical analysis-comparison of PPDI values with yield results. To evaluate whether the PPDI could accurately characterize yield losses in production fields, we also compared the preplant index values and their estimated risk levels with the yields from those same fields. We were able to obtain yield data from 109 fields between 2003 and 2007. These fields were classified into the three risk categories (low, moderate, and high) based on the index values, and means were computed for the PPDI values and corresponding yield parameters: root yields, sucrose concentration, and estimated recoverable sucrose yields. Analysis of covariance (ANCOVA) was used to evaluate the relationship between the vari-

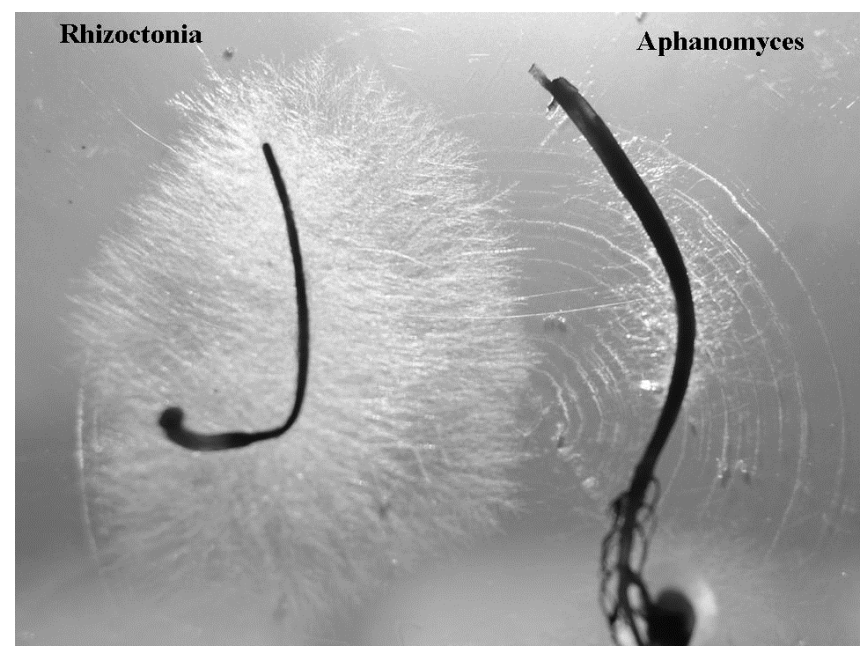

Fig. 1. Characteristic hyphal growth in culture of Aphanomyces cochlioides (right) and Rhizoctonia solani (left) emerging from infected seedlings plated at the same time. Note the slower growth with curly hyphae of $A$. cochlioides compared with the more expansive, feathery growth of $R$. solani hyphae. Medium is one-half strength potato dextrose agar. ous yield parameters and the PPDI among fields for different years. ANCOVA is a special type of regression analysis where several regression lines are fit simultaneously that may have different intercepts and slopes. ANCOVA was conducted for each yield parameter separately, where a line was fit for each collection year and tested whether the slopes of the lines differed significantly. ANCOVA has been used in previous studies to model the relationship between disease level and plant yield and is applicable when data from several locations and years generate a sufficiently broad range of responses necessary for fitting the different lines $(12,13)$.

\section{Results}

More than 800 fields were tested with this method between 2003 and 2007 (Table 1). Yield data were obtained from 109 of the test fields within this time period, with fields estimated as having high, moderate, and low risk numbering 27, 21, and 61, respectively (data not shown). The yields obtained from these same fields over this 5-year period revealed the existence of a very strong relationship between the PPDI and resulting root and sucrose yields. These data also showed that the fields with higher disease indices also resulted in lower tonnage and recoverable sucrose per hectare (Table 2). Correspondingly, those fields with the lowest disease indices produced superior yield parameters, with the moderate risk fields being intermediate (Table 2). For example, over the 5-year period, those fields predicted to pose a low risk, based on DI values, resulted in higher root yields by 13.4 metric tons and almost $2,600 \mathrm{~kg}$ of recoverable sucrose per hectare compared with the high risk fields (Table 2).

ANCOVA of DI values against yield parameters. The ANCOVA results supported our hypothesis that the PPDI test could accurately predict potential root rot problems prior to planting. The analyses indicated a significant overall negative linear relationship between root yields and the DI (Fig. $2 ; b=-0.12, P<$ $0.05, R^{2}=0.40$ ); however, slopes did not differ significantly between years. To maintain consistency with the data from recoverable sucrose, slopes from all 5 years are also included in Figure 2. In addition, the overall negative linear relationship between DI and recoverable sucrose was significant $\left(b=-44.4, P<0.05, R^{2}=\right.$ $0.39)$; however, the slopes differed significantly across years $(P<$ $0.05 ; b_{03}=-0.93, b_{04}=-0.33, b_{05}=-0.31, b_{06}=-0.59$, and $b_{07}=$ -0.88 ) and are presented separately in Figure 3.

Table 1. Frequency of root rot pathogens detected from disease index soil samples and root samples submitted to Panhandle Plant Disease Diagnostic Laboratory (2003 to 2007)

\begin{tabular}{lcc}
\hline Pathogen & $\begin{array}{c}\text { Disease index } \\
(\boldsymbol{\%})\end{array}$ & $\begin{array}{c}\text { Root rot } \\
(\boldsymbol{\%})\end{array}$ \\
\hline Aphanomyces cochlioides & 33 & 8 \\
Pythium spp. & 41 & 4 \\
Rhizoctonia solani & 58 & 24 \\
Fusarium spp. & 15 & 19 \\
Beet necrotic yellow vein virus & - & 15 \\
Total samples & 825 & 1,265 \\
\hline
\end{tabular}

Table 2. Average preplant disease index values and yield components obtained from 109 fields (2003 to 2007) in relation to the three different risk assessment categories, as determined by the disease index ${ }^{\mathrm{z}}$

\begin{tabular}{lcccc}
\hline $\begin{array}{l}\text { Risk } \\
\text { assessment } \\
\text { category }\end{array}$ & $\begin{array}{c}\text { Disease } \\
\text { index }\end{array}$ & $\begin{array}{c}\text { Root yield } \\
\text { (metric } \\
\text { tons/ha) }\end{array}$ & $\begin{array}{c}\text { Sucrose } \\
\text { concentration } \\
(\%)\end{array}$ & $\begin{array}{c}\text { Recoverable } \\
\text { sucrose } \\
(\mathbf{k g} / \mathbf{h a})\end{array}$ \\
\hline Low & $14.86 \mathrm{a}$ & $57.7 \mathrm{a}$ & $17.53 \mathrm{a}$ & $10,094 \mathrm{a}$ \\
Moderate & $37.23 \mathrm{~b}$ & $50.5 \mathrm{~b}$ & $17.27 \mathrm{~b}$ & $8,689 \mathrm{~b}$ \\
High & $57.35 \mathrm{c}$ & $44.3 \mathrm{c}$ & $16.81 \mathrm{c}$ & $7,532 \mathrm{c}$ \\
\hline
\end{tabular}

${ }^{\mathrm{z}}$ Means within columns followed by different letters are statistically different according to Fisher's protected least significant difference test $(P$ $<0.05)$. Note how all values for the low-risk category are statistically better that those of the moderate- and high-risk categories, while the moderate-risk values are intermediate between the low and high. 
The overall slope of the regression line for root yield was -0.1212 , which indicated that, for every unit increase in the DI, the root yields in the tested fields were reduced by 0.27 metric tons $(270 \mathrm{~kg})$ per hectare. Similarly, the slope of the line for sucrose yield was -44.40 , which predicted that the recoverable sucrose yield would decrease by $20 \mathrm{~kg} / \mathrm{ha}$ for every unit increase in the DI. The reasons the slopes differed significantly across years for recoverable sucrose is unknown.

Other considerations. This soil test has additionally revealed some previously unknown aspects pertaining to the ecology and pathogenicity of these soilborne fungi. First, it has revealed the importance and ubiquitous nature of $R$. solani residing in production soils throughout the Central High Plains. Over the 5-year period for which this project is being reported (2003 to 2007), $R$. solani was the most commonly identified pathogen, being detected from $58 \%$ of the collected PPDI soil samples (Table 1). Rhizoctonia root rot was additionally more consistently found infecting crops in higher numbers during the season, based on sugar beet samples collected by the senior author or submitted to the Panhandle Research and Extension Center Plant Disease Diagnostic Laboratory by Western Sugar Coop agriculturalists and consultants (Table 1). Thus, in the case of this pathogen, the DI results correlated with the incidence of the pathogen during the season throughout the region.

Conversely, the incidence of Aphanomyces root rot submitted to the laboratory was erratic from year to year between 2003 and 2007 , averaging only $8 \%$ of the samples received (Table 1 ). However, this pathogen was identified from $33 \%$ of the fields over this period (Table 1), indicating that its presence was common and pervasive but nonconducive environmental conditions discouraged the development of severe disease problems.

Second, we have learned about the relative importance of $R$. solani compared with $A$. cochlioides and other root pathogens. $R$. solani was much more aggressive, infecting seedlings more quickly than $A$. cochlioides. In general, symptoms of infection by $R$. solani were evident within 4 to 5 days after emergence while those of A. cochlioides were not observed until 10 to 12 days after emergence.

Finally, the PPDI test also readily identified Pythium spp. infecting seedlings from soils (Table 1), causing symptoms indistinguishable from those of $R$. solani. Its aggressiveness was also similar to $R$. solani in terms of rapid infections becoming apparent within a week of emergence but was not as consistently detected throughout the course of the month-long assay. When a Pythium sp. was present, it infected seedlings within the first 2 weeks, whereas $R$. solani was often identified causing disease on seedlings throughout the entire 30-day time period $(8,9)$.

\section{Discussion}

The original idea for this concept came after discussions with growers on whether we could determine proactively which root diseases may or may not appear during the season, and was initially designed as a service project for sugar beet producers within the Western Sugar Cooperative. However, we have additionally been rewarded with a number of unforeseen benefits and knowledge as a result of this work.

Over the yield collection period (2003 to 2007), we observed significantly increased sugar $(2,600 \mathrm{~kg} / \mathrm{ha})$ and root yields (13.4 metric tons/ha) from those fields that tested as a low risk through the use of the DI procedure, compared with the high-risk fields (Table 2). Predictably, the moderate-risk fields produced results that were intermediate between the high and low indices (Table 1). ANCOVA comparing the yield component affiliations with DI tell a similar story, with the exception of sucrose concentration (data not shown). Its relationship with DI was not as strong as that with root and recoverable sucrose yields (Figs. 2 and 3). Therefore, these results indicate that accurately predicting root disease potential from $R$. solani and A. cochlioides from preplant soil tests is a viable option for disease management.

Our improved knowledge of the pathogens themselves and their biological activity have been a major benefit. The disease diagnostic laboratory in Scottsbluff has consistently identified $R$. solani as

\section{Root Yield 2003-2007}

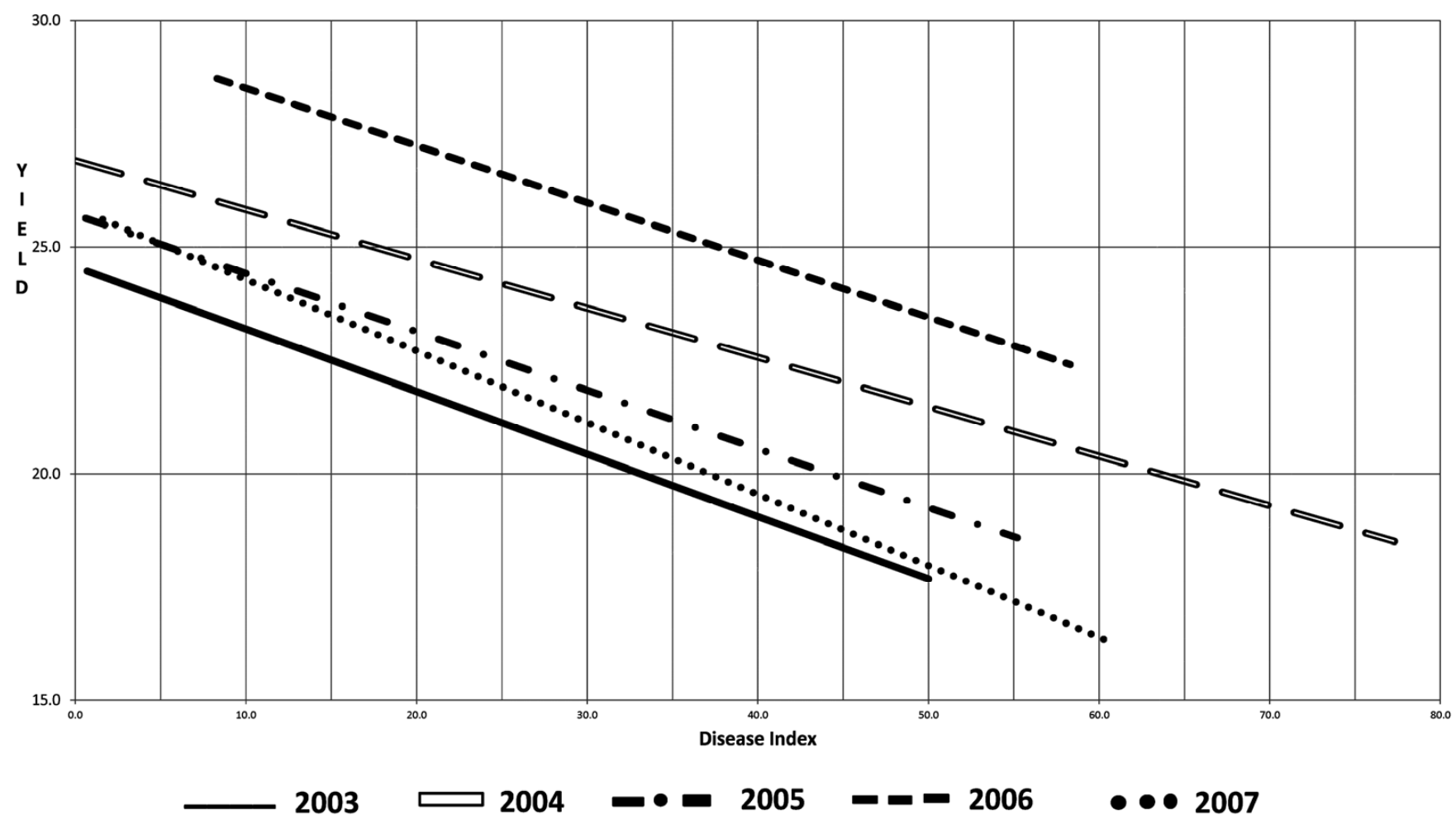

Fig. 2. Linear regression graphs demonstrating the relationship between increasing root yields and decreasing disease indices for the years 2003 to 2007 . Average slope of regression line $=-0.1212$. 
the most frequently occurring of the sugar beet root rot pathogens, based on surveys by the senior author and grower- and consultantsubmitted samples. Diseased samples have originated from all areas of production in the High Plains; therefore, results are considered to also be representative of the region. We have routinely used the diagnostic laboratory over the years in this manner as a mechanism to inform us of prevalent disease problems, reflecting what is occurring in the field.

Furthermore, the ability of the PPDI test to identify different pathogens simultaneously and estimate their relative concentrations from soil samples has demonstrated that $R$. solani is much more aggressive and vigorous in greenhouse tests, infecting seedlings earlier than A. cochlioides. Its distribution and incidence in production soils throughout the region is also more extensive and widespread. For almost a decade at least, $R$. solani has been the most commonly detected pathogen from both preplant soil samples and root disease infections (Table 1). Cumulatively, all of these data suggest that $R$. solani is a more important pathogen and poses a greater risk for damage in this region than A. cochlioides, also making it a more critical target for management efforts.

The sporadic and inconsistent incidence for the root rot phase of Aphanomyces root rot between 2003 and 2007 suggests that it was not overly damaging in production fields in the mid- to late 2000 s, after being very widespread and problematic throughout the late 1990 s and early 2000s. However, this region experienced an extended drought for almost a decade (much of it during the 5-year period of 2003 to 2007). Even with routine irrigation, in many cases, conditions were still not conducive for optimal disease development by A. cochlioides. Nevertheless, the PPDI still detected $A$. cochlioides consistently from grower-submitted soil samples, illustrating the it was still present in production soils.

Pythium spp. were also readily identified from the index tests (from more than $40 \%$ of samples), yet this pathogen has not tradi- tionally been considered an important factor in yield losses in most areas of Nebraska, Colorado, or Wyoming. Pythium root rot is seen infrequently in this area but, when it does occur, the species most commonly identified is Pythium aphanidermatum, after soil temperatures increase in midsummer $(6,10)$. It is unknown which or how many species may be involved with infecting seedlings in the index tests. However, the results here demonstrated that a high number of fields infested with Pythium spp. are present in this region. These data are apparently not reflective of root disease potential for sugar beet production in the Central High Plains but could still be useful in areas where Pythium spp. are known or suspected to induce stand establishment problems. Therefore, this test could serve in this additional capacity for other regions or crops potentially susceptible to Pythium spp.

Several previous studies have addressed this forecasting concept with similar efforts to predict potential problems for sugar beet root disease caused by $A$. cochlioides $(4,24)$. All have had certain limitations, including effects of adverse (dry) weather conditions, confounding effects of other diseases and pests, and various production practices that varied among fields and producers. Nevertheless, this concept has also provided promise for predicting Aphanomyces root rot from greenhouse assays $(3,24)$.

We believe that the PPDI concept is an improvement upon the earlier developed methodologies. For example, PPDI is more versatile by being capable of identifying multiple soilborne pathogens simultaneously, instead of $A$. cochlioides only. Another benefit is a faster turnaround period for growers. The PPDI test can be completed more rapidly than the soil assay developed by Windels and Nabben-Schindler (24) because only seedling infection is considered and the test is not extended to establish root disease ratings. We also have an advantage in our region, compared with other sites, by being capable of comparing greenhouse test results with yield data, reflecting more consistent conditions for disease devel-

Sugar Yield 2003-2007

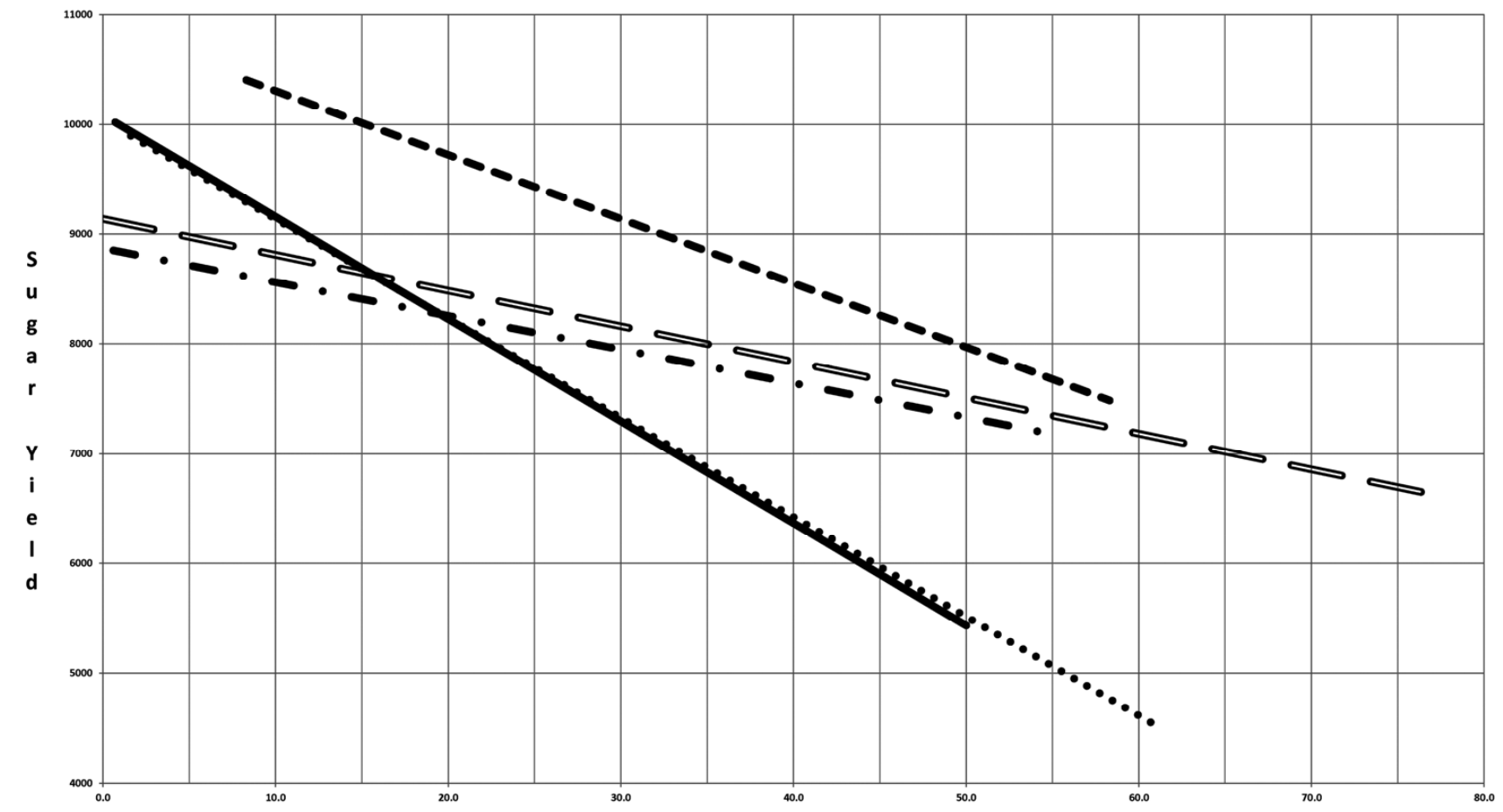

Disease Index

Fig. 3. Linear regression graphs demonstrating the relationship between increasing sugar yields and decreasing disease indices for the years 2003 to 2007 . Average slope of regression line $=-44.0$. 
opment from the field due to the practice of routine irrigations in this region rather than depending on natural precipitation.

The unique relationship between seedling and root disease for both pathogens also favors this test. Because both pathogens cause seedling disease and a chronic root rot during the season $(2,6,9,22,23)$, comparisons are allowed to be made between the yield results and the preplant soil assay from the same fields.

Our test is also heavily weighted toward early infection, based on Ewaldz's soil assay (3). This idea compensates somewhat for situations where seedlings being infected later in the assay (weeks 3 and 4) would likely not die, compared with those infected in the first week. Nevertheless, the later-affected seedlings would often still contribute to an overall incidence approaching $100 \%$. Therefore, this index was constructed by Ewaldz on this basis for emphasizing early attacks (3). Due to the discovery from this study that $R$. solani infects seedlings much earlier than A. cochlioides, this test also appears better suited for estimating populations and potential effects of $R$. solani but may also underestimate populations of A. cochlioides. However, it still appears to work sufficiently for A. cochlioides because we have never observed a discrepancy between the results of the DI and root disease issues in the field involving this pathogen.

One of the limitations with the PPDI test is that it will not effectively predict the root diseases rhizomania or Fusarium yellows or root rot in the same manner. Their presence in soils can be evaluated but requires different types of greenhouse tests with longer time durations. The two Fusarium root diseases are regionally important, particularly from specific areas of Colorado and Montana, yet this index does not detect their presence as effectively in the seedling stage.

Conclusions. The PPDI test has been demonstrated experimentally to accurately predict potential root disease issues from $A$. cochlioides and $R$. solani for area sugar beet growers in western Nebraska, southeastern Wyoming, and northeastern Colorado. This information will assist growers in making management decisions before planting based on the estimated level of risk in those fields obtained from the DI procedure. For example, if a grower had two fields that were tested with the index procedure, and one resulted in a $10 \%$ higher index value than the other, then this test would, in theory, predict that the field with the higher index would yield 2.7 metric tons $(270 \mathrm{~kg}) / \mathrm{ha}$ lower than the field with the lower index value, with an additional reduction of recoverable sucrose of 200 $\mathrm{kg} / \mathrm{ha}$, provided nothing is done to mitigate the potential problem.

This service has been adopted by many growers throughout the region, including two of the highest acreage producers in $\mathrm{Ne}$ braska. The participation of these two growers alone represents approximately $15 \%$ of the sugar beet acreage in Nebraska. Other growers throughout the region are also routinely using the results of these tests in a variety of ways, including cultivar selection, choosing potential fungicide seed treatments (different fungicides are required for the two pathogens), being prepared to spray fungicides (a number of fungicides are currently labeled for $R$. solani, including those in the strobilurin, trizaole, and carboxamide classes), or selecting or eliminating specific fields to be planted to sugar beet.

This is exactly what we envisioned when we began investigating our new technique in 2003. It is very gratifying to see it being used in a number of different ways and we hope that, as the sugar beet leaders in Nebraska and other states in the Cooperative continue to promote this service, others will follow suit.

Although we have not collected yield information since 2007, we continue to provide this service for assessing risk of root disease issues prior to each planting season to interested growers throughout the Western Sugar Cooperative region, consisting of producers in Nebraska, Colorado, Wyoming, and Montana. By identifying potential disease problems early, growers have more time to better evaluate their options, thereby proactively making more economically sound management decisions.

\section{Acknowledgments}

We thank C. Carlson and B. Hawley for technical assistance throughout the duration of this study and Western Sugar Cooperative growers and agriculturalist for their assistance and support and the Joint Research Committee for partial funding of this work.

\section{Literature Cited}

1. Carling, D. E., and Sumner, D. R. 1992. Rhizoctonia. Pages 157-165 in Methods for Research on Soilborne Phytopathogenic Fungi. L. L. Singleton, J. D. Mihail, and C. M. Rush, eds. American Phytopathological Society, St. Paul, MN

2. Edson, H. A. 1915. Seedling diseases of sugar beets and their relation to root-rot and crown-rot. J. Agric. Res. 4:135-168.

3. Ewaldz, T. 1992. Determining the risk of damping-off in sugar beets. Bull. OILB/SROP 15:169-171.

4. Fink, H. C., and Buchholtz, W. F. 1954. Correlation between sugar beet crop losses and greenhouse determinations of soil infestation by Aphanomyces cochlioides. Am. Soc. Sugar Beet Technol. 8:252-259.

5. Harveson R. M. 2000. First report of Aphanomyces root rot of sugar beet in Nebraska and Wyoming. Plant Dis. 84:596.

6. Harveson, R. M. 2006. Identifying and distinguishing seedling and root rot diseases of sugar beets. Plant Health Progress. doi:10.1094/PHP-20060915-01-DG

7. Harveson, R. M. 2006. Using a preplant soil test to estimate beet root disease. The Sugarbeet Grower, November/December issue.

8. Harveson, R. M. 2007. Predicting disease severity for sugar beet root rots using a pre-plant soil disease assay. Pages 197-202 in: Proc. ASSBT 34th Biennial Meet.

9. Harveson, R. M. 2009. Seedling diseases. Pages 21-24 in: Compendium of Beet Diseases and Pests. R. M. Harveson, L. E. Hanson, and G. L. Hein, eds. American Phytopathological Society, St. Paul, MN.

10. Harveson, R. M., Hein, G. L., Smith, J. A., Wilson, R. G., and Yonts, C. D. 2002. An integrated approach to cultivar evaluation and selection for improving sugar beet profitability: A successful case study for the Central High Plains. Plant Dis. 86:192-204.

11. Kerr, E. D., and Watkins, J. E. 1980. A composite of fungus and nematode diseases of sugarbeet. NebGuide G80-491, Univ. Nebr. Coop. Ext.

12. Lindgren, D. T., Eskridge, K. M., Steadman, J. R., and Schaaf, D. M. 1995. A model for dry bean yield loss due to rust. HortTechnology 5:35-37.

13. Madden, L. V. 1983. Measuring and modeling crop losses at the field level. Phytopathology 73:1591-1596.

14. Papavizas, G. C., and Ayers, W. A. 1974. Aphanomyces species and their root diseases in pea and sugarbeet. U.S. Dep. Agric. Tech. Bull. 1485.

15. Park, J. L., and Grau, C. R. 1992. Aphanomyces. Pages 27-30 in: Methods for Research on Soilborne Phytopathogenic Fungi. L. L. Singleton, J. D. Mihail, and C. M. Rush, eds. American Phytopathological Society, St. Paul, MN.

16. Ruppel, E. G., Schneider, C. L., Hecker, R. J., and Hogaboam, G. J. 1979. Creating epiphytotics of Rhizoctonia root rot and evaluating for resistance to Rhizoctonia solani in sugarbeet field plots. Plant Dis. Rep. 63:518-522.

17. Rush, C. M. 1990. Seedling and root rot diseases of sugar beet in Texas. Tex. Agric. Exp. Stn. AREC-CTR 90-4.

18. Schneider, C. L. 1978. Use of oospore inoculum of Aphanomyces cochlioides to initiate blackroot disease in sugarbeet seedlings. J. Am. Soc. Sugar Beet Technol. 20:55-62.

19. Schneider, C. L., Ruppel, E. G., Hecker, R. J., and Hogaboam, G. J. 1982. Effect of soil deposition in crowns on development of Rhizoctonia root rot in sugarbeet. Plant Dis. 66:408-410.

20. Sneh, B., Burpee, L., and Ogoshi, A. 1998. Identification of Rhizoctonia species, 3rd ed. American Phytopathological Society, St. Paul, MN.

21. Windels, C. E. 2000. Aphanomyces root rot on sugar beet. Plant Health Progress. 10.1094/PHP-2000-0720-01-DG

22. Windels, C. E., and Harveson, R. M. 2009. Aphanomyces root rot. Pages 24-27 in: Compendium of Beet Diseases and Pests. R. M. Harveson, L. E. Hanson, and G. L. Hein, eds. American Phytopathological Society, St. Paul, $\mathrm{MN}$.

23. Windels, C. E., Jacobsen, B. J., and Harveson, R. M. 2009. Rhizoctonia root and crown rot. Pages 33-36 in: Compendium of Beet Diseases and Pests. R. M. Harveson, L. E. Hanson, and G. L. Hein, eds. American Phytopathological Society, St. Paul, MN.

24. Windels, C. E., and Nabben-Schindler, D. J. 1996. Limitations of a greenhouse assay for determining potential of Aphanomyces root rot in sugarbeet fields. J. Sugar Beet Res. 33:1-13. 